\title{
Impact of Classroom Lay-out into Proactive Learning
}

\author{
DOI: https://doi.org/10.47175/rielsj.v2i2.255
}

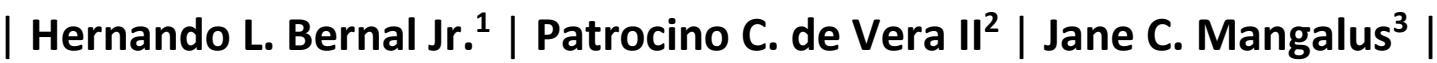

${ }^{1}$ General Education

Department, FEU-NRMF, Quezon City Philippines

${ }^{2}$ Senior High School, Irisan National High School, Irisan, Baguio City, Philippines

${ }^{3}$ Department of Arts and Letters, Mapua University, Intramuros, Manila, Philippines

${ }^{1}$ bhambernal@gmail.com, 2patdeveraii02202018@gmail.com, 3jcmangalus@mapua.edu.ph

ABSTRACT

This study experimented in the use of classroom lay-out, its effectiveness inside the classroom, and its preference for its location. Classroom lay-out involves the learners, their seat locations, and the teacher's preferences. It used the qualitative inquiry with the phenomenology approach in interpreting the results from the students' responses. Total enumeration sampling was used where all the students in the Senior high school of Irisan National High School were part of the data gathering respondents. Responses to queries were collected through interviews with the respondents. Results showed that the learners would prefer the teacher to identify where they are to be seated instead of them choosing their own seats. Classroom lay-out might entail an effective strategy to boost the academic performance of a learner, especially in the researcher's classes in terms of self-assessment and showing of authority. However the learners think of assessing themselves in terms of their seat location and the classroom layout, they still see the teacher as the one in authority in leading the effectiveness of the classroom lay-out.

KEYWORDS

classroom lay-out; seat location; effectiveness
\end{abstract}

\section{INTRODUCTION}

There had been a lot of research pertaining to teaching instruction and learning, however, there are a few studies on seat locations. Seat locations, according to Fernandes et al. (2011) is the student's location in the classroom. There has been a belief that students are motivated based on where they were seated inside the classroom. That is, these students' academic performance were also affected. Still, some beliefs state that the students who seat at the back are the bad students while students who seat at the front row are the good students (Fernandes et al, 2011). However, Bicard et al, (2012) indicated that seating location is the 'easiest, most cost-effective classroom management tactics' that is in favour of the teachers as they studied. This seating location might be of help to the teachers in minimizing disruptive behaviours inside the classroom. Communication, however, is related to seating arrangement in terms of effective classroom understanding (McCorskey \& McVetta, 1978). Having seat location as an important factor in classroom management, there is a need to identify if seat location matters to Senior High learners. These senior high learners are basically the first and second year students of the tertiary level in the Philippines.

It is due to this equivalent that there was a belief that learners who are in the tertiary level could already choose in which seat they want to position themselves. It is as they are already of age to identify their learning suitability. This research paper aims to determine the applicability of this notion on which seats the learners prefer, and who should make the decision as to where students sit: teachers or learners.

All senior high school learners were able to seat accordingly as they were provided with enough number of armchairs. Thus, all the senior high school learners were accommodated 
and each learner has his or her own chair. The classroom of these senior high learners are wide enough to accommodate at least 25 to 50 learners. These learners have an arm chair and a base for seating. Thus, any seating arrangement could be possible to do inside the classroom. Seating arrangement, according to Fernandes et al. (2011), refers to the design of the chairs and desks, in the setting of the research paper, arm chairs, inside the classroom.

For the past two years, the researcher had a different seating arrangement with the senior high school learners. As the first year of senior high was implemented last school year, 2016 to 2017, the researcher did an alphabetical order seating arrangement. The seating arrangement was done in a three column, two row arrangement. This was done again during the first semester of the current year, in grade 11. The seating arrangement was done in a three row, two column arrangement. For the grade 12, the researcher had opted of having the learners sit wherever they want. It is because the learners had been classmates for the previous year, thus, concluding that they know well each other in terms of academic and learning performances. However, this second semester of the School year 2017-2018, the researcher did another seating arrangement. 1. The males were seated in-between females with only two rows and three columns. It was because the females got higher ranks in terms of academic performance than males. This is for them to guide the males in cases of academic need but not necessarily providing them answers to formative assessments. This strategy was also done to the Grade 11 students this semester. However, after three weeks, these grade 11 learners were transferred to the school library. Since the library was not meant to be a classroom, these learners were provided with six 48 inches long table instead of individual arm chairs. This has led to the learners not knowing their own seating location and having to choose their own places. It was with these different situations that the researcher chose seat locations as the main variable of this study to identify its relevance in the learning of students. In the process, the researcher will be observing the different learning behaviour of the students. As observed in the past, some of the learners were complaining that their seatmates were not cooperative during seatmate discussions among the grade 12 and grade 11 students. Another complaint that the researcher had received was the disruptive behaviour of the seatmates. A female senior high school learner abruptly said, in a class discussion with the researcher, their teacher, and the researcher quotes, "Ma'am, o, si ginugulo n'ya ako (Madam, look, he/she is disturbing me)." It may sound like a childish thing to do as a senior high learner and young adult, however, this is pertaining to their learning per se. These two situations were just two of the incidents that had happened in terms of their seating locations as teacher's choosing for grade 11 and student's choosing for grade 12. Hence, the researcher would like to identify the relation of seating location with the learning of the subject matter of the researcher of the senior high school learners.

From the different researches mentioned, there was no research on seat location that focuses on Senior high school learners. In addition, this research might help the researcher on choosing how and where the senior high learners be located in preparation for the tertiary level. Also, there has not been a research on seat location in terms of having the change of seat arrangement in a semestral basis or yearly basis. This research paper might contribute to the appropriate teaching and learning of senior high school subjects in relation with the appropriate activities to be conducted by the teacher considering the seat locations of learners.

\section{Objectives}

This research paper aims to identify the preferred seating arrangement to senior high school students that may have an effect on their learning in their Communication Arts subjects under the researcher's classes. The main question, "What is your understanding about seating 
arrangement?" is asked to the respondents. All other questions were asked to them in support of their preferred seating arrangement during the data gathering / interview.

\section{RESEARCH METHODS}

This study employed qualitative research design with phenomenological approach. The researcher focused on the meaning of the year-round phenomenon of seating arrangement or learners' seating location.

The researcher has prescribed two seating arrangements for the senior high learners to choose from. The first set is the front (first two tables near the teacher's desk), middle (middle two tables from the teacher's desk), and back (last two tables from the teacher's desk). The second set is the front (first two columns from the teacher's desk), middle (third and fourth columns from the teacher's desk), and back (fifth column from the teacher's desk). After the learners indicated their seat preference, they told their reasons for it. Then, the researcher let the students actually seat in their preferred seat locations for the first two weeks of February. Then, the researcher gave an assessment to the learners to evaluate their learning once seated in their preferred seat location. On the third and fourth week, the process of seat preference was repeated. Then a comparison of their learning assessment was done to identify the effectiveness of their learning. This process was done until the third week of March 2018. This is to validate the assessed learning outcomes by the students.

Another technique that the researcher employed in gathering data is through participant observation and unstructured interview. The respondents' academic performance was also examined.

The data used the thematization process. It used the cool and warm analysis in analysing the data. In the technical aspect, it is with the collation of interview answers that the research question was answered. In the same manner, the settings, environments, surroundings, and the perspectives of having seat locations were considered for the results of the study.

The researcher took into consideration the anonymity and the confidentiality of the answers of the respondents in answering the survey questionnaires as well as the validity of their answers during the interview. The researcher made sure to ask the learners if they have any intention of withdrawing from the research in which the researcher would be glad to free them. The researcher abided by the rules in conducting a study. Lastly, the researcher took into account the right of the respondents to know the results of the conducted research. Thus, a dissemination of the results is implemented.

\section{Participants}

The researcher used total enumeration sampling in this study. The participants are all the senior high learners enrolled at Irisan National High School. It is composed of 66 senior high learners. There are a total of 26 grade 11 learners with 10 males and 16 females and there are 40 grade 12 learners with 17 males and 23 females. Thus, no selection to be employed as all the learners will be involved.

\section{RESULTS AND DISCUSSION}

These results came from the senior high school learners' responses. These responses came from six grade 11 and six grade 12 learners. The main question asked was the learners understanding on seating arrangement. Then, the follow-up question was on the learners' preference on seating arrangement. 


\title{
Seating arrangement by the Senior High school learners
}

The senior high school learners have defined seating arrangement in two different ways. First is that seating arrangement is an act of the teacher to manage the seats for the purpose of evaluation. The second is that the seating arrangement is the result of the classroom layout based on the student's personality.

\section{Seating arrangement is an act of the teacher to manage the seats for the purpose of evaluation}

\begin{abstract}
'Seating arrangement? It would give sense to the seat and to the students. Because without it, you are kwan.. without the seating arrangement, ma'am, the seat students deal because eventhough there are students, there are seats, umm... there are there would be no arrangement so it will be useless. In the meantime the other referred as a.. ma'am.. as a reflection of the students or of the teacher for the teacher umm..it would know ay! He or she would know where to put the student when he or she wants the student to develop and for the student it would be there way to give us their way to what they are showing is true or not.'
\end{abstract}

The definition of grade 11 to seating arrangement was that seating arrangement is a location in which the teacher told them to be seated. This answer proved that the students are waiting for the teacher to let them seat where they are without giving them options as to where. In any case, these learners were put there to do their own way of getting acquainted with their seatmates which could result to behaving or misbehaving.

For grade 12,

'Seating arrangement is where you want to seat and where the teacher wants you to seat.'

Most of them preferred seating in front and a few would like to seat in the middle. It is surprising to indicate that only one or two would like to seat at the back. They preferred the front part because they could focus on the teacher and since they were near the roadside, sitting in front would give them a leeway to better hear what the teacher has to say and as to what her instructions were. The grade 12 learners preferred the alphabetical type of seating arrangement as their class performances were improving. This resulted to their preference of letting the teacher be the one to dictate where a learner should sit. It was because these learners believe that teachers know best where to assign learner's seats to be able to lead in the discussion and be part of a stronger group in terms of group activities or pair activities.

Meeks et al. (2013) research on the impact of seating location to student's performance states had proved that the learners sitting in front of the classroom does not necessarily outperformed learners seating at the back part of the classroom. The learners' understanding of seating location might lead to the learners' thinking of having higher grades when in front rather than being at the back. These learners might promote higher motivation in front and lower motivation at the back. However, it might also suggest that learners are focused on the evaluation as the end of their seating location instead of the learning process in the duration of the school term.

\section{Seating arrangement is the result of classroom lay-out based on the student's personality}

'Seating Arrangement also defines...Ay! Ano parang.. doon natin makikita kung ano ung personality nung tao kung madali ba siyang mag-adjust doon sa environment na kinalalagyan nya . For example, ano, yong tahimik na tao, insatead na mapunta siya sa harap napunta siya sa likod tapos ung mga nakapaligid sa kanya mga maiingay. It's either magaadjust siya or pakikisamahan nya yong mga taong katabi nya, magiingay din siya or magreremain siya sa perst... characteristic nya tapos iown na rin nya.' 
For the definition of seating arrangement by the grade 11 learners, it was an act of the teacher to manage seats for the purpose of self-evaluation. This is also the result of classroom lay-out based on the student's personality.

For the grade 12 learners, seating arrangement is a form of self-assessment. This also shows the teacher in authority as in:

'a.. uhhum.. a.. excuse me po.. umm.. for me, seating arrangement seating arrangement, yeah! ..hehheh... ummm... seating arrangement.. mahirap mag-isip (silence)... ummm... english, ma'am, English? Umm.. pano ba ienglish 'yon, ma'am.. yong saan ka inasign ng teacher kung saan ka uupo... hehhe...seating arrangement 'yon 'yong kung saan kami inasign ng teacher kung saan kami uupo and kung saan nya comport.. ummm... kung saan nya kami gusto ilagay na.. dun.. kung comfortable dun, gusto ba namin dun or not.. hehhe...thank you..'

These definitions of the two highest grade levels in the secondary level could indicate that their maturity is gearing towards responsibility and evaluating one's understanding and focus. This could also mean a different viewpoint as to who they are seated with, their comfortableness with their seatmates who could have an impact on their learning academically. Another viewpoint is the classroom lay-out which may connote the arrangement of seats in the classroom in a U-shape, triad, or double shape. However the learners think of assessing themselves in terms of their seat location and the classroom layout, they still see the teacher as the one in authority in leading the effectiveness of the classroom lay-out.

Regardless of gender (Meeks et al., 2013) in indicating if seating arrangement has an impact or not, the results show that the learners' personality is a case for defining the seat location. It might be possible that the teacher considers the learners' personality in choosing their seat locations. This might be an indication of an effective classroom management.

\section{The seat preference of senior high school learners and their effects}

There are different themes that came out after the interview done with the senior high school learners regarding their seat preferences. These are due to concentrating, comforting, and seating appointment. Its effects are due to environmental and societal factors, interesting and physiological effect, and being safe and verbally communicating.

\section{Concentrating, comforting, and seating appointment}

Concentrating, comforting, and seating appointment were identified to be the themes on their preferred seating arrangements for senior high school learners. Concentration is often mentioned in grade 11 as most of them preferred seating in front, a number preferred seating in the middle, and minimal would like to seat at the back. One of the learners said:

'I prefer to sit infront for, because I can concentrate more and uhm I can see and understand what is written or uhh presented in front.'

In addition, another learner stated:

'I will sit, sit in front because, because I can hear the voice of the teacher more. It could be and loudly than I sit in the back, at the back.'

From the statements, it is possible that the learners perceive a teacher factor when preferring to seat in front comparing to seating at the back. It would also be possible that these learners had experienced some teachers who they could barely hear what he or she was trying to say in class.

Being in the middle preferences make the learners comfortable as they would like to have their confidence intact. As one of the learners stated, 
'mas prefer ko pong umupo sa middle part kasi, kasi ah mas comfortable ako dun. Kung saan ako comfortable mas ma-gain ko yung ano yung confidence ko, tiyaka mas maka concentrate ako sa lesson.'

In addition, these learners could concentrate by looking at the teacher without any hassle as they presumed that the teacher is looking in front or at the back part. Their confidence might be due to the lay-out position of their seats in which they do not feel any worries or discomfort either with their seatmate as it was the teacher who assigned them their seats. A learner stated that:

'I preferred to sit in the middle because, it is my seating arrangement and also into binigay ay yun yung binigay na upuan ng teacher sa amin.'

Those who preferred seating at the back were conscious into having other learners look at what the learner in front is doing. It was because they presumed that the teacher is not really aware of the learners at the back. There was a learner who stated: 'I prefer to sit at the back kasi dun ko mas uhm ayaw kong may taong nakaupo dun sa likuran ko na kung anoanung ginagawa.'

Fernandes et al. (2011) agreed that learners should have also felt the need to create their own personal space to control social interaction within the classroom. It would be possible that these learners were conscious of their classmates seated in front of them which they always find to be disagreeable on their part.

\section{Environmental and societal factor effects}

For the effect of their seating arrangement regarding the researcher's classes, the learners said that it all depended upon the learners. Truly, a learner said,

'It's up on us to understand, the student and academic performance is not based on where we will gonna sit in the class but it's up on us to have a higher grade or lower grade but as a student, it is our responsibility.'

That is, regarding their knowledge and their capacity to understand the lesson at hand and not regarding as to where they were seated. They said that their grades were not dependent on their seat location or the classroom lay-out but on how they had done their reviews and performances in class. In addition, the effects of the preferred seating arrangement of the senior high school learners include environmental and societal factors. These environmental factors take on the noise,

'Ma'am kasi pag ano, 'pag nagsama-sama yung mga madadaldal especially yung mga boys na mga loko-loko is parang walang mangyayari sa kanila kasi sama-sama sila, babagsak pag walang nakikinig na isa hindi makikinig din yung isa.'

teacher leading or deciding,

'Ma'am because you know and how the students' performance, performance if he or she performs well or not para malead sila sa mga, mga yung mga nagfe-fail para mahila sila.'

and students' comfortableness.

Kumbaga ma'am kasi may time ba halimbawa, kunwari, parang may uhm yung may, kapag nasa likod ka hindi mo makikita then (noise) hindi ka comfortable dub sa place mo, parang naaapektuhan yung performance mo '.

These responses might be visible to the learners as these indicate the students' learning and understanding regardless of their seating arrangement. Noise happens when the learners were comfortable with their seatmates thus affecting their class concentration. Teacher leading or deciding as to where a learner seats is environmental as the researcher had the learners' seat according to three seating preferences. First was alphabetical. Second was boy- 
girl alternation. Third was the learners' own choice. It might be possible that the learners see the teacher in-charge of the seating arrangement which may have been what had happened with them in their past year levels. The respondents of this research paper preferred the alphabetical way of doing it. It was because their last names match their heights, their interests, or their comfortableness. In some special cases as the learners were at the back but were near-sighted, the researcher gives consideration and asked other learners who prefer to be transferred. Learners who preferred were either far-sighted or do not seek comfortableness with the given seat location.

\section{Interesting and physiological effect}

'I prefer to sit Infront kasi uhm parang kapag sa harap ka uupo parang doon ka naka focus, yung maiintindihan mo and malalaman mo yung mga lessons, or mga lessons na tinatackle ng teacher.'

Seating infront means being focused on the teacher and the topics as well. In addition, those who were seated in front were learners who have problems with their heights. Surprisingly, there were learners who indicate that those who were seated at the back were interested with what was being tackled in front. Therefore, it would be possible that if the topics are of interest, it does not matter where the learners seat.

\section{Being safe and verbally communicating}

'I prefer to sit in the middle because it's the safest, why? Because if in case of recitation you have time to think of your answer and if in case that young teacher at magtatawag ng classmate kung may ganun siya, you will not. Yung you're safe, hindi ka niya itutruro agad because you're in the middle.'

Learners being in the middle would like to be very safe in their positions. They would either be worried of their positions in the academics or would not like to be in the centre of attraction in the class. In addition, these learners seating in the middle are more into looking at the eyes of the teacher or whoever was in front. It could be possible that these learners have an optical vision as they could see other gestures outside the ordinary.

Even Fernandes et al. (2011) research states that seating arrangements could influence how students relate to on teacher's influence in class control. In addition, as the learners selfselect their own seating arrangement, they are also relating to their participation in the classroom. Having the learners do a self-select of their own seating arrangement could positively affect their academic achievement and might promote better learning experience.

\section{CONCLUSION}

Classroom lay-out includes seating location of the learners in class. It would be according to teacher preference or learners' preference. As a result of this study, the learners would prefer the teacher to identify where they are to be seated instead of them choosing their own seats. This may have resulted as they saw the teacher as someone in authority for they are still in the senior high school. In addition, classroom lay-out might entail an effective strategy to boost the academic performance of a learner, especially in the researcher's classes in terms of self-assessment and showing of authority. It was found out that the highest achievers in grade 11 were seated at the back part and still others were in front. In the same manner with grade 12, the highest achievers could be found in front while others were seated in the middle. However, most of them were seated in the middle. Therefore, it might have just been an educated guess to indicate that those who are seating in front are the geniuses of the class or a learner becomes one when seated near the teacher's table. 


\section{REFERENCES}

Bicard, D., Ervin, A., Bicard, S., \& Baylot-Casey, L. (2012). Differential effects of seating arrangements on disruptive behaviour of fifth grade students during independent seatwork. Journal of Applied Behaviour Analysis, 2, 407-411.

Fernandes, A., Huang, J., \& Rinaldo, V. (2011). Does where a student sits really matter? The impact of seating locations on student classroom learning. IJAES, 10, 66-78.

McCorskey, J. \& McVetta, R. (1978). Classroom seating arrangements: Instructional communication theory versus student preferences. Communication Education, 27, 99111.

Meeks, M., Knotts, T., James, K., Williams, F., Vassar, J. \& Wren, A. (2013). The impact of seating location and seating type on student performance. Education Sciences, 3, 375386. 